\title{
Development of Hearing Perception and Phonological Awareness: The Contribution of Digital Educational Resources
}

\author{
Dalila Gonçalves \\ Escola Superior de Educação \\ Instituto Politécnico de Castelo Branco \\ Castelo Branco, Portugal \\ dalila.goncalves@hotmail.com \\ Henrique Gil \\ Age.Comm - Instituto Politécnico de \\ Castelo Branco \\ Castelo Branco, Portugal \\ hteixeiragil@ipcb.pt
}

\author{
Liliana Matos \\ Escola Superior de Educação \\ Instituto Politécnico de Castelo Branco \\ Castelo Branco, Portugal \\ liliana.matos.pt@gmail.com
}

\author{
Rita Ribeiro \\ Escola Superior de Educação \\ Instituto Politécnico de Castelo Branco \\ Castelo Branco, Portugal \\ rtaragonez@gmail.com
}

\begin{abstract}
One of the basic prerequisites for acquiring reading and writing is phonological awareness. A child with hearing impairment does not correctly identify speech sounds, reproduces errors in reading, and subsequently in writing. The development of auditory perception and phonological awareness are essential for the complete development of the child. The purpose of this research was to promote the use of digital educational resources, to develop skills in the phonological process and to implement play activities that motivate the child to learn. It is intended to answer the research question: "Can digital educational resources be a facilitator of the promotion of auditory perception and phonological awareness in a hearing impaired child?". After the theoretical framework, an intervention plan was drawn up and through the digital educational resources: "Cochleando", "Comunikit: Rhymes and Initial Sounds" and the Sign Language Dictionary "Spread the Sign", we conclude that they are an asset to development of phonological awareness in the teaching-learning process.
\end{abstract}

Keywords - Phonological Awareness, Auditory Deficiency, Auditory Perception, Digital Educational Resources

\section{GLOBAL RESEARCH FRAMEWORK}

The research is related to the use of digital educational resources in an educational context, so that they can foster a playful context that provides better and more learning that has a direct translation in educational success. A child with a hearing impairment has a handicap that puts them in a context of inequality with their peers.

This research, whose theme is "The Development of Auditory Perception and Phonological Awareness: The Contributions of Digital Educational Resources", aims to contribute to the linguistic development of the participating child and to verify if the digital educational resources (Cocleando; Comunikit: Rhymes and Sounds Spread The Sign) may be a facilitator in the teaching-learning process. Digital educational resources are now considered an added value in the teaching-learning process. Students are motivated and committed when using the technologies present in their daily lives.

This research assumes a qualitative nature, privileged an action research approach. This type of study allows us to evaluate and make adjustments that are deemed relevant in order to improve the intervention. It is intended to plan to intervene, and to succeed. The investigation is non-formal, given that the intervention took place in the context of school supervision, outside of school. However, the research team planned its intervention taking into account the Individual Educational Program (IEP).

\section{THE CHILD WITH HEARING DISABILITIES}

Hearing impairment is the total or partial sensory deprivation of hearing, and can be described from the organic characteristics. The classification of this problem is performed taking into account the location of the lesion, the moment it begins and the degree of severity [1]. Deafness makes sound communication impossible with the outside world. Thus, the child's development may be impaired, particularly if deafness is pre-linguistic or pre-locutory, that is, if it occurs in the child before the emergence of speech. When deafness occurs after the child has acquired orality, it is called post-locutory and the implications have a minor impact on development [1].

Decree-Law No. 54/2018 establishes the principles and rules that guarantee the inclusion of each and every student. Children with hearing impairment should benefit from bilingual education by acquiring sign language as their mother tongue and Portuguese written as a second language [2].

The introduction of cochlear implant revolutionized the hearing rehabilitation of patients with severe and profound sensorineural deafness. This electronic device is surgically inserted into the inner ear, replaces damaged or missing cochlear sensory cells and directly stimulates the remaining fibers of the auditory nerve. Cochlear implants ensure improved auditory perception and promote stimulation in individuals with severe / profound bilateral sensorineural hearing loss [3]. The hearing and psychosocial benefits resulting from the implantation of this device have been documented, considering this method of rehabilitation as an effective and safe technique in the treatment of severe to profound deafness, improving the quality of life and promoting its integration in an active society [3].

\section{HEARING PERCEPTION AND PHONOLOGICAL AWARENESS}

We understand hearing perception as the interpretation and understanding of the sound environment that surrounds 
us in our brain. The ear encodes the sound messages and the brain has the ability to reconstruct and select them thanks to the intervention of attention and memory [4]. In this way we are able to recognize different voices, understand speech and follow a conversation. Speech is organized in such a way that it is because of its ease of understanding, making reading and alphabetic writing difficult.

Language is the ability of any human being to acquire and use the language of their community [5]. Acquisition takes place during childhood, it occurs naturally and spontaneously, only if the child is exposed to others [6]. From the early life of the baby, who uses the vowel sounds produced through the larynx, to the mastery of the phonemes of the language, in different contexts of syllable, word or phrase, begins the mastery of phonology [7]. In the sound sequence that corresponds to a word, we can identify units that, when replaced, change the meaning. These units are called phonemes. The smallest element of meaning in a word is the phoneme that can be confused with sound [7].

There is an upward relationship regarding the influence of phonological awareness on a child's reading success and a strong relationship between rhyme awareness and later reading performance [8]. Phonological awareness is the ability to reflect on the sound segments of oral words. It is the ability to analyze and manipulate sound segments of different sizes such as syllables, intrasyllabic units and the phonemes that integrate the words [9].

\section{DIGITAL EDUCATIONAL RESOURCES}

Digital educational software and resources are considered digital entities that are specifically produced to support teaching and learning. Thus, we can consider an educational game as a digital educational resource since it is designed to develop pedagogical skills. It is intended to improve the acquisition of competences when these softwares are used in learning contexts, both in the classroom context and in specialized support and explanations [10].

The most sought after software by children are educational games. Children feel challenged and this valence can be used to stimulate higher levels of motivation and involvement in activities that can provide conditions for learning to take place. [11] The best way to integrate these resources into the school environment implies that teachers feel involved in this process and the learning experiences they want to create from the use of technologies. These games challenge children and lead to content acquisition and new skills as a learning facilitator. Increasing student motivation, self-esteem, and autonomy are the main advantages of using games to boost classes [12]. In this sense, the application of digital educational resources to educational contexts is considered a pedagogical added value.

\section{METHODOLOGY}

The study is qualitative in nature, favoring a descriptive and interpretive action research methodology [13]. This whole reflective process was based on field work, with the research question "Can digital educational resources be a facilitator of the promotion of auditory perception and phonological awareness in a child with hearing impairment?" The objectives that guided the research were to:

- Promote the use of Digital Educational Resources.

- Develop skills of the phonological process..

- Implement playful activities that motivate the child to learn
An intervention plan was implemented based on the student's IEP guidelines. We intend to address the difficulties evidenced in terms of auditory perception and phonological awareness. As data collection techniques, field notes were chosen to record the child's attitudes during the sessions and the results presented by digital educational resources.

During the implementation of the plan, the moments of reflection came after each session, which led to its reformulation whenever we considered it necessary.

In order to answer the research question and to verify the improvement of the difficulties detected with the use of digital educational resources. An exercise was developed for the development of phonological awareness, based on the National Program of Portuguese Teaching (PNEP) [14], using an auxiliary digital educational resource. Spread The Sign is a Sign Language dictionary that assisted the practical exercise as the use of LGP is constant in the student's life.

The participant in this study was chosen for convenience, given that the student who enjoys school supervision in a private study center. The child is 10 years old and born with hereditary bilateral congenital deafness. Has 2 cochlear implants placed at 2 and 9 years. According to information from PEI and under the DL n54 / 2018 benefits from: Specific Curriculum Adaptations; Attends Bilingual Reference School; Support from Portuguese Sign Language Teacher (LGP), LGP Interpreter and Speech Therapist.

\section{A. Digital Educational Resources}

The digital educational resources chosen for this research took into account the specific characteristics of the study child. It should be noted that no software was chosen for commercial purposes:

- «Cocleando»: is an application that allows you to develop auditory perception in children with cochlear implants, developed by Cochlear. It is an educational game organized into 4 areas of development of auditory perception, namely Detection, Differentiation, Identification and Understanding. It presents graphs as in Fig. 1. for the child's display performance and evolution in each area which facilitates the detection of strengths and weaknesses.

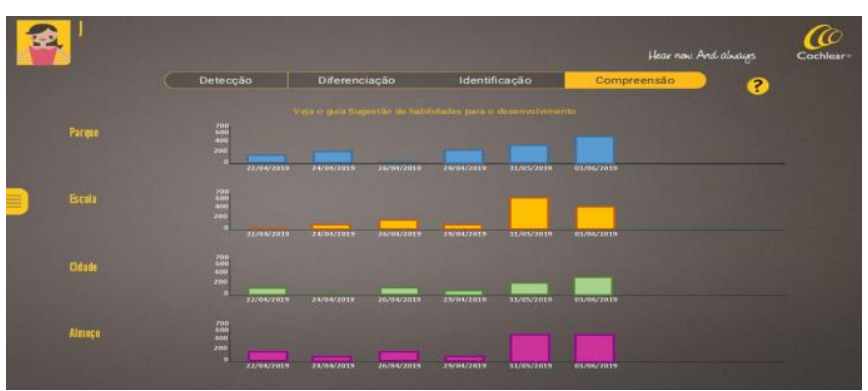

Fig. 1. Performance chart by development area

- «Comunikit: Rhymes and Initial Sounds focuses on the ability to recognize rhymes, syllables and early phonemes. The choice fell on this application, after several researches because it associates image with sound and there is always the possibility of repeating the indication, which in the case of the child with hearing impairment is an asset. This educational game is organized into 3 areas of phonological awareness development, with games and levels of 
increasing difficulty, Early Phonemes, Early Syllables and Rhymes. Displays the result obtained as Fig. 2. and allows sharing of the results by email.

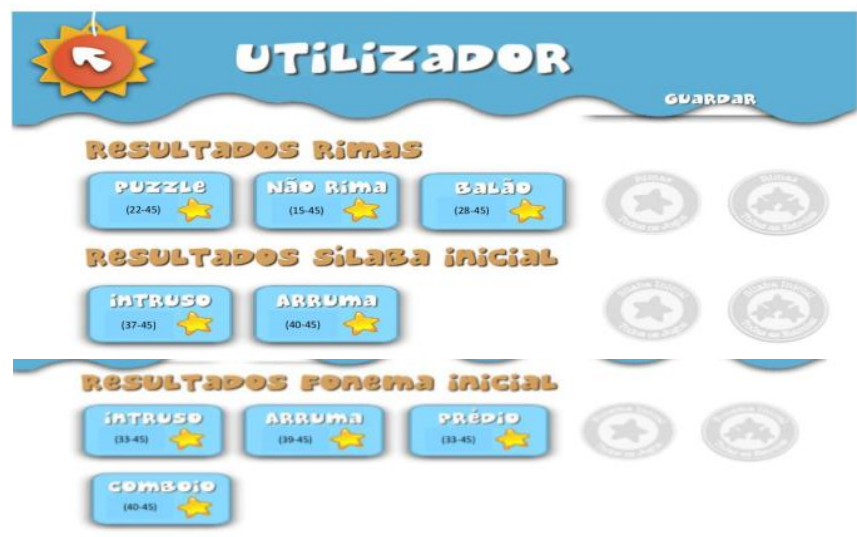

Fig. 2. Scores: «Comunikit: Rhymes and Initial Sounds»

- As LGP, the study participant's first language, it was necessary to use the software «Spread The Sign» which is a Sign Language dictionary to assist the written exercise. The choice of this application is due to the fact that no special equipment is required and it allows to choose the language. Present the alphabet with pictures and interpret words or short phrases through short videos.

All applications are available on the Play Store, and Cocleando and Comunikit - Rhymes and Initial Sounds have a small cost associated with the full version are available on the Play Store, with 'Cocleando' and 'Comunikit - Rhymes and Initial Sounds' having a small cost associated with the full version.

\section{B. Intervention Plan}

An intervention plan was elaborated, table I. with two weekly sessions of 30 minutes each. The sessions take place in the context of accompaniment to the student in a study center. A total of 20 sessions were held, which is equivalent to approximately 10 hours of work. Considering the logistics and the time, a larger number of sessions was not possible.

\begin{tabular}{|l|l|}
\hline 4 Sessões & \begin{tabular}{l|} 
Cocleando \\
\hline 12 Sessões
\end{tabular} \\
\hline 2 Sessões & $\begin{array}{l}\text { Comunikit - Rimas e Sons Iniciais } \\
\text { Cocleando }\end{array}$ \\
\hline 2 Sessões & PNEP; Spread The Sign \\
\hline
\end{tabular}

Implementation of the intervention plan began on April 22 and ended on June 7 and a 12 inch tablet was used.

\section{PRACTICAL IMPLEMENTATION ACTIVITIES: DATA ANALYSIS}

In implementing the defined intervention plan it was found that the child easily used all digital educational resources, understood the icons of different menus. To evaluate and develop auditory perception we started the intervention with the game «Cocleando» in which the student showed some difficulty in the Identification and Understanding domains where she achieved low score as we can see in table II.

\begin{tabular}{|l|l|l|l|l|l|l|l|}
\hline Deteção & Pontos & Diferenciação & Pontos & Identificação & Pontos & Compreensão & Pontos \\
\hline Palhaço & $300 / 300$ & Padaria & $400 / 400$ & Músicas & $100 / 600$ & Parque & $200 / 700$ \\
\hline Arvore & $250 / 300$ & Frutaria & $350 / 400$ & Cozinha & $150 / 600$ & Escola & $150 / 700$ \\
\hline Aquário & $300 / 300$ & Varal & $350 / 400$ & Supermercado & $200 / 600$ & Cidade & $100 / 700$ \\
\hline & & & & Loja de brinquedos & $250 / 600$ & Almoço & $150 / 700$ \\
\hline
\end{tabular}

TABLE II. SCORE: COCLERANDO

These domains require greater auditory perception to identify or understand the instructions given. For example, identify a song associated with a particular symbol or understand the indication, "The backpack is a boy with a cap" and make this indication. Auditory memory failure is an important skill that needs to be developed, as it is necessary to retain the information conveyed in the sentences for the time needed to process them and then extract meaning from what was indicated or read [15].

These difficulties led the child to show an attitude of denial vocalizing "I don't understand" and an attitude of giving up "I don't want this one". Upon reflection we considered that it would be appropriate to suspend this game after 4 initial sessions.

The following sessions explored the digital educational resource 'Comunikit - Rhymes and Initial Sounds'. Easily reached the first 10 levels of each game with 2 or 3 stars showing greater difficulty in rhymes.

In the phonological development games, it was easily distinguished between the phonemes and the initial syllables. It should be noted that it was necessary to hear the word a few times despite the associated images. Regarding the Rhymes area, the child shows more easily in those where there is a complete correspondence of sounds. The child only showed more tiredness in the games that work in this area, but never mentioned wanting to stop.

After 12 sessions, over $80 \%$ of the Initial Phoneme and Initial Syllable levels were reached and only approximately $50 \%$ of the Rhyme game levels.

Given that the child participating in the study showed no refusal to play 'Cocleando' again, namely the two areas with the lowest score, 2 more sessions were planned. He showed interest and commitment, which led him to improve the results initially obtained, as we can see in table III.

\begin{tabular}{|l|l|l|l|l|l|}
\hline Identificação & $\begin{array}{c}\text { Pontuação } \\
\mathbf{1 0}\end{array}$ & $\begin{array}{c}\text { Pontuação } \\
\mathbf{2 0}\end{array}$ & Compreensão & $\begin{array}{c}\text { Pontuação } \\
\mathbf{1 0}\end{array}$ & $\begin{array}{c}\text { Pontuação } \\
\mathbf{2 0}\end{array}$ \\
\hline Músicas & $100 / 600$ & $200 / 600$ & Parque & $200 / 700$ & $600 / 700$ \\
\hline Cozinha & $150 / 600$ & $400 / 600$ & Escola & $150 / 700$ & $650 / 700$ \\
\hline Supermercado & $200 / 600$ & $300 / 600$ & Cidade & $100 / 700$ & $400 / 700$ \\
\hline Loja de brinquedos & $250 / 600$ & $400 / 600$ & Almoço & $150 / 700$ & $600 / 700$ \\
\hline
\end{tabular}

TABLE III. FINAL SCORE: «COCLEANDO»

We consider that the improvement of phonological skills allowed an improvement in the level of auditory perception. Listening and decoding words positively compromises the 
perception of sounds and, consequently, their comprehension.

In order to verify if the digital educational resources used could be considered a facilitator of the promotion of auditory perception and phonological awareness, in a child with hearing impairment, the researchers elaborated two written exercises for the development of phonological awareness based on the PNEP. As LGP is the first language of the study participant, is part of the study curriculum and is used in everyday life, it was necessary to use the Sign Language Dictionary, «Spread The Sign», because the exercise had no associated images.

In the last two sessions, the student performed a rhyming exercise with some names of classmates and another with common names, Fig. 3.

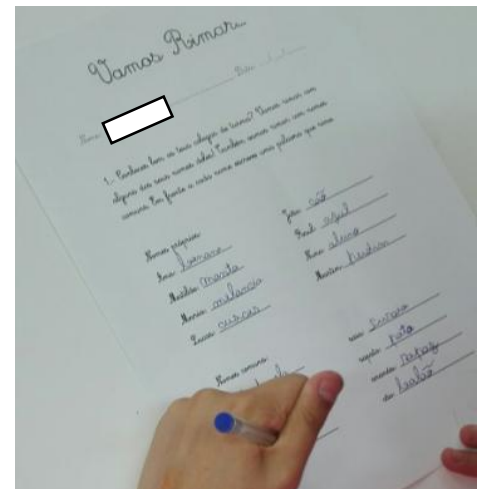

Fig. 3. Child doing a written activity

Just missed 1 rhyme, (Matilde / blanket) because it did not associate a total match of sound / graphemes. In the others, it used this strategy and was successful.

It should be noted that the child showed a high level of satisfaction when he found that he just missed a rhyme. It was noticeable the involvement during the sessions, the child felt a progress of his performance, showed wanting to explore more digital educational resources, contributed to raise his self-esteem. Any purchase made is always an asset and a contribution to overcome the difficulties highlighted.

\section{CONCLUSIONS}

During the implementation of the intervention plan there was no doubt about the effectiveness of digital educational resources. Although the research is restrictive because only one child participates in the study, we can conclude that the educational games used were adequate to their learning needs, promoting an increase in phonological awareness and auditory perception.

The researchers' main concern was to develop an intervention plan that would be effective for the child to achieve academic success. The available digital educational resources can be a facilitator of academic success, not only for children with hearing impairment, but for all students.
Note that the 20 sessions despite the positive result obtained, more training time could provide better results. With the data obtained we mention that a phonological awareness training program helps in the development of phonological skills and auditory perception.

We found that the satisfactory results obtained positively reflected the reading skills associated with LGP and writing.

In conclusion, we consider it urgent that initial and continuing teacher education does not neglect the implementation of digital educational resources in the daily planning of classroom activities. More training is needed in this area to sensitize and equip professionals with digital skills to enable them to be applied in an educational context, especially with children in inclusive education.

\section{REFERENCES}

[1] Goldfeld, M. (2003). Fundamentos em fonoaudiologia. Rio de Janeiro: Guanabara Koogan.

[2] Decreto-Lei n. ${ }^{054 / 2018}$ de 6 de julho - Ministério da Educação. (2018).

[3] Gerard, O. (2013). Cochlear Implants - Science, Serendipity, and Success. The New England Journal of Medicine. Obtido em 2 de junho de 2019, de https://www.nejm.org/doi/full/10.1056/NEJMp1310111

[4] Mendes, A., Afonso, E., Lousada, M., \& Andrade, F. (2013). Desenvolvimento fonético-fonológico do português europeu: contribuições para a prevenção do insucesso escolar. Em L. Veloso, Sucesso Escolar. Da compreensão do fenómeno às estratégias para o alcançar (pp. 59-76). Lisboa: Mundos Sociais.

[5] Sim-Sim, I., Silva, A., \& Nunes, C. (2008). Linguagem e comunicação no jardim de infância: Textos de apoio para educadores de infância. Lisboa: Ministério da Educação.

[6] Andrade, A., \& Lourenço, M. (2015). Educar para a diversidade e desenvolver a consciência fonológica: propostas pedagógicasdidáticas. Aveiro: Universidade de Aveiro.

[7] Rios, C. (2013). Programa de Promoção do Desenvolvimento da Consciência Fonológica. Viseu: Psicosoma.

[8] Castelo, A. (2010). Processos Fonológicos e consciência linguístico: estudo-piloto com alunos do $1^{\circ}$ ano do ensino superior. $X X V$ Encontro Nacinal da Associação POrtuguesa de Linguistas. Porto.

[9] Alves, D., \& Lousada, M. (2016). Avaliação fonética e fonológica: instrumentos, metodologias e interpretação dos resultados. $A$ Perturbação Fonológica: Avaliação e Interpretação. Aveiro: Escola Superior de Saúde.

[10] Tchounikine, P. (2011). Computer Science and Educational Software Design. Berlim: Springer.

[11] Ramos, J., Teodoro, V., \& Ferreira, F. (2011). Recursos educativos digitais: reflexões sobre a prática . Em M. d. Ciência, Cadernos SACAUSEF VII (pp. 11-34). Lisboa: Ministério da Educação e Ciência.

[12] Klein, C. (2006). A arte de ensinar utilizando softwares educativos. Brasil: Centro Universitário Feevale.

[13] Coutinho, C. (2011). Metodologia de investigação em ciências sociais e humanas: teoria e pratica. Coimbra: Almedina.

[14] Duarte, I. (2008). PNEP O Conhecimento da Língua: Desenvolver a Consciência Linguística. Lisboa: Direção-Geral de Inovação e de Desenvolvimento Curricular.

[15] Lopes, J. (2006). Desenvolvimento de Competências linguísticas em Jardim de Infância. Manual de Atividades. Porto: Edições ASA. 